\title{
RECENT ADVANCES IN APPLICATIONS OF ACTIVE CONSTITUENTS OF SELECTED MEDICINAL PLANTS OF DHOFAR, SULTANATE OF OMAN
}

\author{
ISRAR UL HASSAN ${ }^{1 *}$, MOHAMMED IDREES ${ }^{2,3 *}$, GOWHAR AHMAD NAIKOO ${ }^{2}$, LUAY RASHAN ${ }^{3}$, \\ ABDELBARY ELHISSI ${ }^{4}$, WILLIAM ZIMMERLE ${ }^{5}$, WAQAR AHMED ${ }^{6}$
}

${ }^{1}$ College of Engineering, Dhofar University, P0 Box 2509, PC 211, Salalah, Sultanate of Oman. ${ }^{2}$ Department of Mathematics and Sciences, College of Arts and Applied Sciences, Dhofar University, PO Box 2509, PC 211, Salalah, Sultanate of Oman. ${ }^{3}$ Frankincense and Biodiversity, Laboratory, Dhofar University, PO Box 2509, PC 211, Salalah, Sultanate of Oman. ${ }^{4}$ College of Pharmacy, Qatar University, PO Box 2713 , Doha, Qatar. ${ }^{5}$ University of Pennsylvania, Museum of Archaeology and Anthropology, Consulting Scholar-Near East Section, Philadelphia, PA 19104 USA. ${ }^{6}$ School of Mathematics and Physics, College of Science, University of Lincoln, Lincoln, LN6 7TS, United Kingdom.

*Email: midress@du.edu.om, i_hassan@du.edu.om

Received: 29 November 2016, Revised and Accepted: 08 January 2018

ABSTRACT

The Dhofar region of Oman is extremely opulent in plant biodiversity in comparison to other parts of the country. Most of the cultivated, medicinal and wild plants of the region are available in the mountainous side and hilly areas of Dhofar. The plants produce products from primary metabolism and others from secondary metabolism. On the basis of active constituents plants can be categorized into two groups:

1. Medicinal plants and

2. Aromatic plants.

Over 250 complex chemicals have been recognized and extracted from herbal sources. In this review article, we discuss a selection of medicinal plants of the Dhofar region of Oman which are rich in active constituents and through recent reports discuss the application of the most active constituents. Among the medicinal plants of the Dhofar region, frankincense is also a well-known indicator of the region and has a unique position through its medicinal properties of its oil and gum resin.

Keywords: Dhofar, Secondary metabolites, Frankincense, Active constituents.

(c) 2018 The Authors. Published by Innovare Academic Sciences Pvt Ltd. This is an open access article under the CC BY license (http://creativecommons. org/licenses/by/4. 0/) DOI: http://dx.doi.org/10.22159/ajpcr.2018.v11i4.16386

\section{INTRODUCTION}

The Dhofar region of Oman is significant and extremely rich in plant biodiversity in comparison of other parts of the country. Most of the cultivated, medicinal, and wild plant species of the region are found in elevated areas of Dhofar. Medicinal vegetations are the most selected sourced drugs that are able to protect the life of the majority of the world's population. Plants and herbs are the first foundation of treatments available to primitive human being. There are numerous textual references available in literature that describe the use of herbal medicine worldwide for defensive and healing purposes [1,2]. The bioproducts of medicinal plants are very beneficial in a number of ways. Some sections, for example, leaves, root, stem, bark, and sometimes even whole plants are used to create chemical brews that are useful to treat even very common problems such as throat infections and irritation. The products of the plant can be grouped into two categories:

1. Products produced from primary metabolism

2. Products produced from secondary metabolism.

The products of primary metabolism have a direct role in the growth and development of the plants. The majority of the active constituents are the products of secondary metabolism of the plants. Typically in adverse condition, plants shift their metabolism from primary to secondary to protect itself from adverse conditions. Some of the secondary metabolites synthesize in response to injury to plants. Plants accumulate several secondary metabolites to protect themselves against insects, fungi, and herbivorous animals. On the basis of active constituents, plants can be categorized into two main groups: First, medicinal plants and second, essential oils bearing medicinal plants also known as aromatic plants.
The use of oil extracted plants such as castor, garlic, mint, coriander, and opium has been reported from the era of the early civilization of Egypt and was popular among trade goods during the Roman Empire [3]. For example, spices are aromatic or pungent vegetable substances applied in minute amounts to augment, modify or mask the aroma of food [4]. Spices have been used since ancient times for the protection of food products as they possess antiseptic and disinfectant properties [1,2]. They enhance the shelf life of foods by avoiding rancidity and oxidation of lipids [5] or by bacteriostatic or bactericidal activity and antifungal activity. Compounds obtained from plants known as phytochemicals have attracted much attention as natural alternatives to synthetic drugs. These natural products are used as raw materials to synthesize new antimicrobial and antifungal drugs which are relatively safe to humans and help to supply synthetic chemicals. In excess of 250 complex chemical extracts are identified from herbal sources. Ethnobotany is the stream of science that deals with the study of the old-fashioned application of plants for humans and is a very useful way to discover the herbal medicine [6]. Herbal drugs for various societies of poorer nations are found to be more economical in comparison to modern pharmaceuticals. It is well documented that more than $80 \%$ of the population of the third world rely on herbal medicine for their healthcare needs. Societies of developed countries also use herbal components for fragrances and other cosmetic purposes. Various aspects in the study of active constituents have changed and upgraded due to an advance in technology and methodology. Scientists are working hard to ensure quality control, scientific evidence for the efficacy and for the prevention of potential adverse effects of herbal remedies. Active constituents such as alkaloids, flavonoids, flavones, terpenes, and polyterpenes which are present in different organs of the plants have various effects on biological systems. Attention has been geared toward developing new antibiotics which reduce the increasing resistance 
among microorganisms [7]. In this review article, selected medicinal plants of the Dhofar region of Oman which are a rich source of active constituents, advancement of extraction, and isolation technology are addressed together with recent reports on the application of the most active constituent. Among them, frankincense is a well-known indicator of the region and has a unique position due to the medicinal properties of its oil and gum resin.

\section{FRANKINCENSE (BOSWELLIA SPECIES)}

Several of the approximately 25 species of Boswellia, including Boswellia sacra (from the southern Arabian Peninsula), Betula papyrifera (from the tropical Northeast Africa), Boswellia frereana (from Somalia), B. soqatra (from the tropical island of Socatra in the Indian Ocean), and Boswellia serrata (from India) produce a unique oleo-gum-resin from cutting the small ducts in the bark of trees from which the gum resin's frankincense are collected (Photograph 1). Characteristics of the species allow them to be burned as a sweet fumigate as well as to be distilled as a fragrant perfume or often dissolved in water to be consumed for medicinal purposes as a pulmonary antihistamine. This is common traditional practice today among locals living in these regions.

While the etymology of the Anglo-Saxon word frankincense belongs to the French language which means "pure incense," frankincense as a globalized trade commodity in world history is known by various different names in different cultures. Other names for frankincense are Olibanum, Salai guggal, Luban, or Kundur. Linguistically, Olibanum may first appear in ancient cuneiform tablets from third Millennium BC Mesopotamia where it was used as medicinal oil [8]. Kundur, the classical Arabic word for frankincense, can be traced back to the ancient Sanskrit language as the oleo-gum from the B. serrata tree $[9,10]$. As the most renowned plant of Dhofar, the B. sacra frankincense tree is known today as Shajarat al-luban in Dhofari Arabic and as Megerot. In the modern South Arabian Jibbali language of the mountains of Dhofar [11]. Today, the species B. sacra grows from the Hadhramaut in Yemen to Hasik in Dhofar (Map 1; Map 2; Table 1).

In general, in almost all of the cultures where frankincense was traded, it was used for fragrance and fumigating objects used in religious ceremonies. In traditional medicine, frankincense has a unique place among the remedies for treating various disorders [12]. Frankincense was commonly used to treat microbial infections as early as the $11^{\text {th }}$ century. As per the report published by Michie and Cooper [13], the Persian physician and philosopher Avicenna studied the effect of frankincense on urinary disorders such as inflammation and common

Table 1: Main species of Boswellia and their location of cultivation

\begin{tabular}{|c|c|c|c|c|}
\hline $\begin{array}{l}\text { S. } \\
\text { No }\end{array}$ & \multicolumn{2}{|c|}{ Name of species } & \multicolumn{2}{|c|}{ Location of cultivation } \\
\hline 1 & \multicolumn{2}{|l|}{ B. serrata } & \multicolumn{2}{|l|}{ Northwest India } \\
\hline 2 & \multicolumn{2}{|l|}{ B. frereana } & \multicolumn{2}{|c|}{ Somalia and Ethiopia } \\
\hline 3 & \multicolumn{2}{|l|}{ B. papyrifera } & \multicolumn{2}{|c|}{ Ethiopia, Eritrea, and Sudan } \\
\hline 4 & \multicolumn{2}{|l|}{ B. thurifera } & \multicolumn{2}{|c|}{ Yemen, and North and East Africa } \\
\hline 5 & \multicolumn{2}{|l|}{ B. soqotra } & \multicolumn{2}{|l|}{ Island of Soqotra } \\
\hline 6 & \multicolumn{2}{|l|}{ B. sacra } & \multicolumn{2}{|l|}{ Dhofar } \\
\hline \multicolumn{5}{|c|}{$\begin{array}{l}\text { B. serrate: Boswellia serrate, B. frereana: Boswellia frereana, B. papyrifera: } \\
\text { Boswellia papyrifera, B. thurifera: Boswellia thurifera, B. soqotra: Boswellia } \\
\text { soqotra }\end{array}$} \\
\hline S. No & Metabolites & Mai & mponents & Percentage \\
\hline 1 & Resin & Mixt & of terpene & $65-80$ \\
\hline 2 & Gum & Mixt & of polysaccharides & $6-25$ \\
\hline 3 & Essential oil & $\begin{array}{l}\text { Com } \\
\text { Tabl }\end{array}$ & ents are listed in & $5-7$ \\
\hline
\end{tabular}

infections and found that frankincense had an effective role to treat this type of an infection.

Gum resins of Boswellia sp. have wealth of healing properties and used to treat rheumatoid arthritis and other inflammatory diseases [14]. There are numerous reports which explain the importance of frankincense in treating various infectious caused by different pathogens and

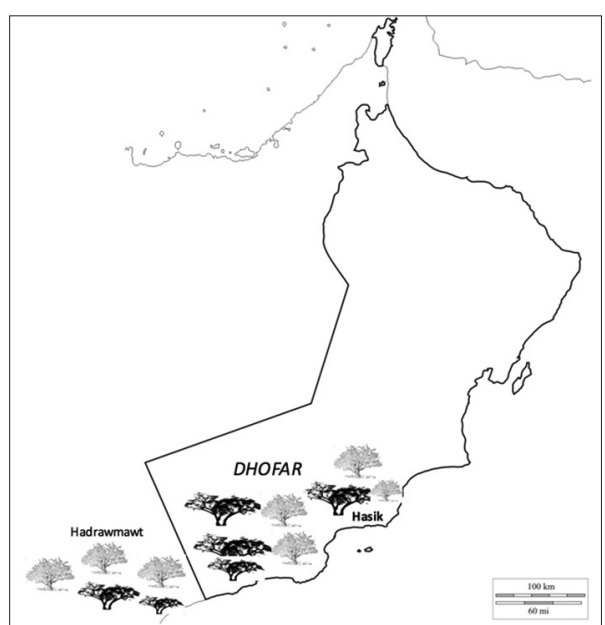

Map 1: Distribution of Boswellia sacra trees from the Hadhramaut (Yemen) to Dhofar (Oman)

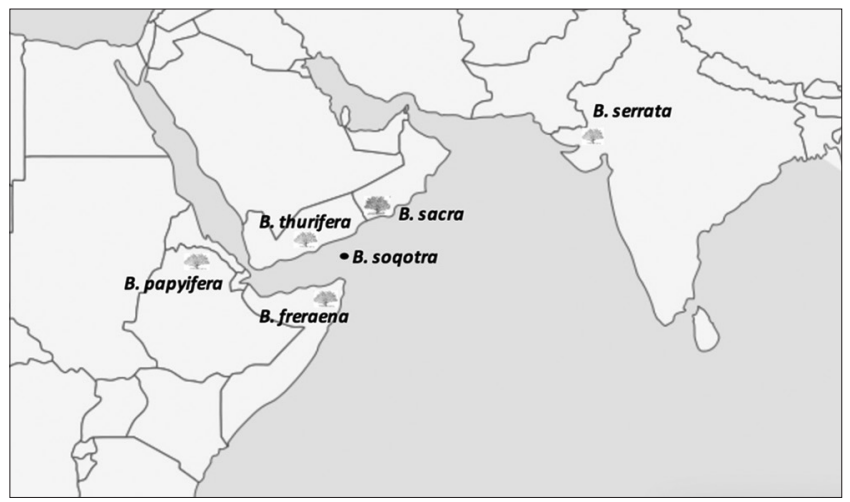

Map 2: Agricultural distribution patterns of the Boswellia species

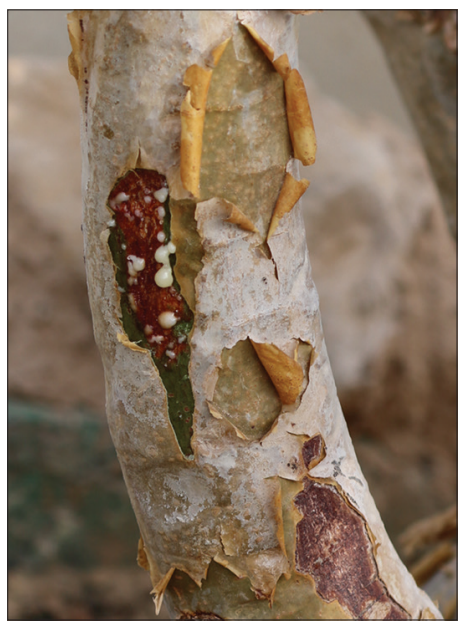

Photograph 1: Boswellia sacra cut from the bark of a Frankincense tree at the site of al-Shishr, Dhofar (Photograph by W. Zimmerle) 
other medical conditions $[15,16]$. The composition of various parts of Boswellia sp. including the component of essential oil is already discussed in detail. We reviewed here the recent use of secondary metabolites extracted from various sources a variety of Boswellia from regions such as Oman, Yemen, and Somalia which are known as major trading centers of frankincense from as early as the first millennium $\mathrm{BC}[17]$.

\section{SECONDARY METABOLITES OF BOSWELLIA SPECIES}

There are various compounds found in Boswellia species, the quantity and quality of these compound changes from species to species that makes every species different from one another (Table 2). The reasons behind these differences are closely related to climate, harvesting time, and geographical conditions $[18,19]$. The leaves extract of Boswellia species contains steroids, terpenoids, fatty acids, tannins, saponins, anthocyanin, leukoanthocyanin, coumarins, emodins, alkaloids, phenols, and flavonoids. The chemical composition of frankincense essential oil can be used as a marker to recognized varieties of frankincense. The important component of Omani and Aden essential oil is $\alpha$-pinene $(43 \%)$ whereas; Eritrean and Turkish essential oils have a high quantity of octyl acetate (52\%). The Indian oil is rich in $\alpha$-thujene (61\% Fig. 1a) [20-24]. The major metabolites of frankincense are highlighted as follows $[25,26]$ :

Monoterpene is a major group (monoterpene hydrocarbons) which is found in frankincense oil up to $40 \%$; however, there are some variations existing among species of Boswellia on the basis of monoterpenes concentration [27]. The main composition of essential oil was $\alpha$-pinene $45.7 \%$, $\alpha$-terpinene $11.5 \%$, and trans-sabinene hydrate. The components of essential oils show variation from species to species, components listed in Table 3 are found in most of the oils extracted from various species of Boswellia [18].

\section{Components of resin}

Like essential oil, the resinous part of frankincense has terpenes such as $\alpha$-thujone (monoterpenes), diterpenes, $\alpha$-and $\beta$-amyrins (triterpenes), boswellic acids (BAs) (pentacyclic triterpenic acids), tirucall-8, and 24-dien-21-oic acids (tetracyclic triterpenic acids). Among these, the $\mathrm{BA}$ is the most important active component of Boswellia species [18] Table 4.

\section{Use of frankincense oil}

Frankincense essential oil is used to treat several inflammatory diseases such as arthritis, bronchial asthma, chronic colitis, and cancer and also used in dermocosmetics, inhalation, and smoking [28-30]. Essential oil also showed antibacterial, antifungal, and immunostimulating activity [31]. The essential oil extracted from B. sacra is generally rich in alpha-pinene. The challenge of microbial chemo control lies in the development of new microbial strains with high resistance to the classical and advance antibiotics [32].

\section{Use of frankincense oil against pathogens}

Researchers concerning the antimicrobial activity of phytoproducts such as phytochemicals, vitamins, and hormones have been studied extensively yet there is little emphasis on the evaluation of the antipathogenic effect of essential oils and extracts [33]. The antipathogenic activities of the essential oils were independently evaluated against fungi, Gram-positive, and Gram-negative bacteria strains. Resins of frankincense destroy the cell wall of the pathogen and prevent protein synthesis in Streptococcus salivarius, Staphylococcus aureus, and Bacillus megaterium [34]. Volatile oils make sensitization of microbial cell contents and have anti-bacterial effects on Staphylococcus epidermidis, S. aureus, Staphylococcus hominis, Bacillus cereus, Proteus vulgaris, Escherichia coli, and Candida albican [35]. Application of frankincense products such as gum, oil, and extracts can significantly decrease in inflammatory indices compared to drug therapy. It is a secure and economical form of herbal drug and may be plausibly used to treat inflammation based ailment of gingival as an accessory to the therapy. The essential oil and methanol extract of Boswellia displayed activity against bacterial spp. than against yeast [36]. Kavanaugh and Ribbeck tested the antimicrobial activity of some essential oils against Pseudomonas aeruginosa, Pseudomonas putida, and $S$. aureus $[34,37]$. However, results obtained by Rashan et al. (2017; unpublished) indicated that no effect of frankincense oil was found on various species of genus Staphylococcus. They are known to taint important tracts such as pulmonary, trachea and urinary tracts, lesions, and scorches. The combined dose of myrrh and frankincense essential oils showed synergistic effects on Cryptococcus neoformans and $P$. aeruginosa [4].

Table 3: Major component of frankincense essential oil

\begin{tabular}{lll}
\hline S. No & Major component & Description \\
\hline 1 & Monoterpene & $\begin{array}{l}\text { Monoterpenes are the major parts of essential oil. To date, there are at least 30 types of monoterpenes } \\
\text { are reported in frankincense oil. Among these, alpha-thujene, E-beta-ocimene (Fig. 1b), camphene, } \\
\text { sabinene (Fig. 1c), myrcene, Alpha-pinene, limonene, alpha-thujene, E-beta ocimene, and camphene are } \\
\text { important and share major part of secondary metabolites }\end{array}$ \\
& $\begin{array}{l}\text { Cembrene (Fig. 1d), isocembrene, verticiol, duva-4,8,13-trien-1,3 } \alpha \text {-diol, thunbergol, duva-3,9,13-trien-1,5 } \alpha \text {-diol, } \\
\text { duva-3,9,13-trien-1 } \alpha \text {-ol-5,8-oxide-1-acetate, duva-3,9,13-trien-1,5 } \alpha \text {-diol-1-acetate }\end{array}$ \\
& Diterpene & $\begin{array}{l}\text { Sesquiterpenes are other major components of frankincense oil. The main sesquiterens are } \\
\text { alpha-cubebene (Fig. 1e), alpha-copaene, betabourbenene, beta-elemene (Fig. 1f), E-caryophyllene, } \\
\text { alpha-humulene, allo-aromandendrene (Fig. 1g), etc. }\end{array}$ \\
& Sesquiterpene &
\end{tabular}

Table 4: Components of resin

\begin{tabular}{lll}
\hline S. No & Type & Role \\
\hline 1 & $\beta$-BA & It can reduce the biosynthesis of DNA, RNA, and protein leukemia cells in human [27] \\
2 & ABA & It also can inhibit the transcription and translation in HL-60 cells [27] \\
3 & 11-KBA (Fig. 1h) & ABA and KBA have similar effects to each other \\
4 & 3-O-AKBA & $\begin{array}{l}\text { The anticancer activity of AKBA is linked with its inhibitory nature to lipoxygenases leading to reduction of cell } \\
\text { proliferation as well as apoptosis induction in cells of tumors } \\
\end{array}$ \\
& & $\begin{array}{l}\text { It has shown a specific inhibitory role in prostate cancer by destroying factor related to receptor 2-mediated } \\
\text { angiogenesis [9] }\end{array}$ \\
\hline
\end{tabular}

BA: Boswellic acid, ABA: Acetyl- $\beta$-boswellic acid, KBA: Keto- $\beta$-boswellic acid, AKBA: Acetyl-11-keto-beta-boswellic acid, DNA: Deoxyribonucleic acid, RNA: Ribonucleic acid, HL: Human leukemia 


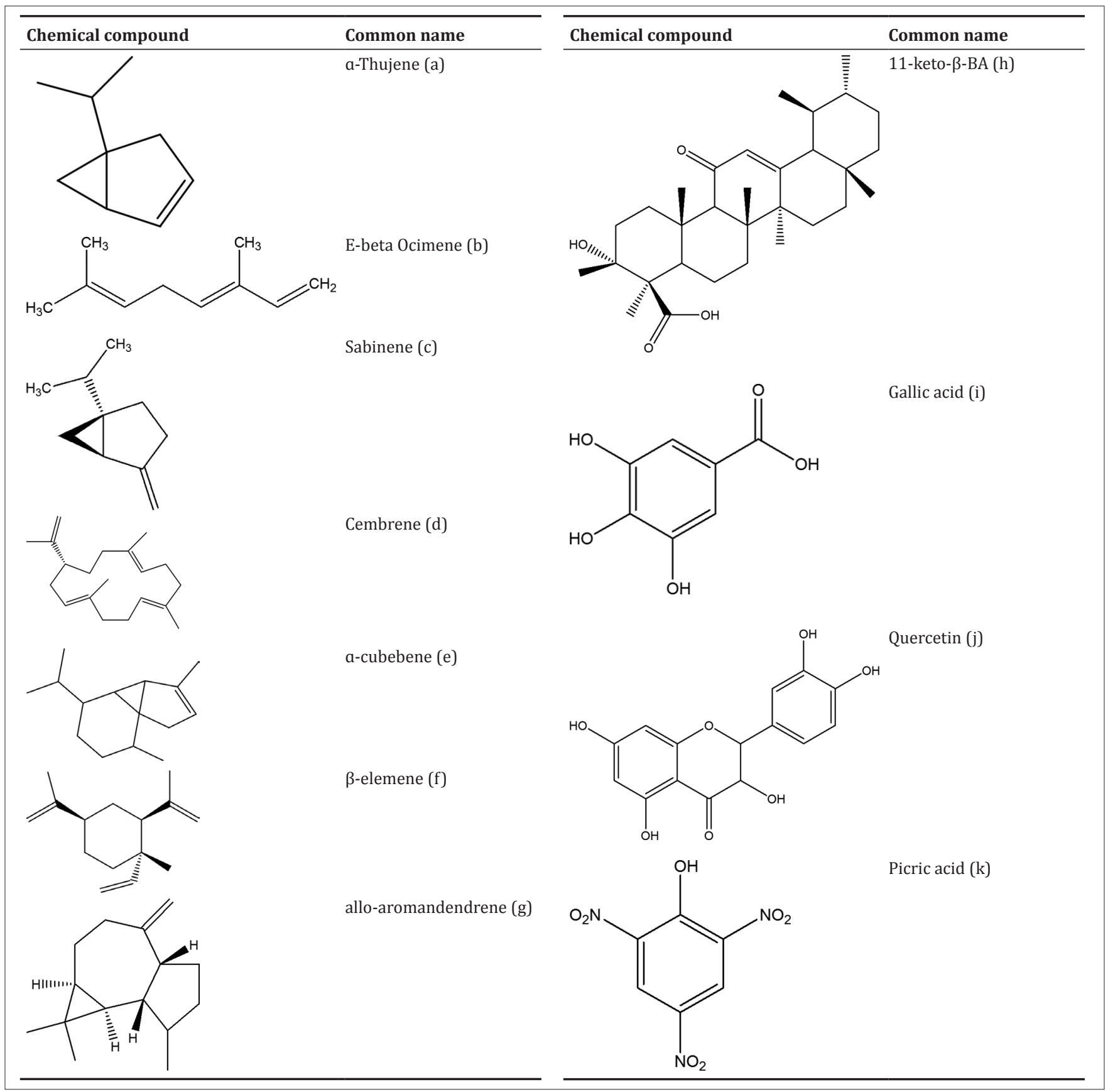

Fig. 1: (a-k) Chemical structures

\section{Use of frankincense oil against cancer}

Resins of Boswellia species have triterpenoids which are responsible for antitumor properties of resin [38]. Resin of Boswellia has four important types of triterpenic acid:

The BA has effect on apoptosis myeloid leukemia cell lines of human beings. B. serrata has pentacyclic triterpenoids which have the ability to reduce the growth and development of cancer in prostate cell [39]. Akt, which is a type of protein kinase, has various roles in cellular functionality such as cell transport, protein synthesis, cell proliferation, and apoptosis. It is also linked with several types of cancer as it can aide to reduce or even stop apoptosis and further, promote the survival of cells. Another secondary metabolite known as tirucallic acid found in gum resin of Boswellia carteri plays an effective role as Akt inhibitors [39]. The finding of the study indicated that application of $3600 \mathrm{mg} /$ day of Boswellia decoction with a concentration of $60 \%$ BA decreased the fluid around the tumor in 8 out of 12 tested patients and it was also noted that damage in brain cell declined by the treatment of the extract [40]. Syrovets et al. (2000) reported that acetyl-BA (ABA) inhibits Topoisomerases I and II $\alpha$ through competition with deoxyribonucleic acid (DNA) for binding to the enzyme [38,131]. In another study, Tatiana et al. detected that acetyl- $\alpha$-BA $(A \alpha B A)$ and acetyl-11-keto- $\beta$-BA (AK $\beta B A$ ) slow down the activities of human recombinant glutathione S-transferase-IкB kinase (IKK) $\alpha$ and His-IKK $\beta$. The lipopolysaccharide (LPS)-triggered induction of tumor necrosis factor- $\alpha$ in monocytes is reliant on IKK activity. These findings provided molecular basis properties ascribed to A $\alpha \mathrm{BA}$ - and AK $\beta \mathrm{BA}$-containing drugs for the anti-inflammatory and suggested that ABAs can be used as a template to develop new therapeutic drugs [38]. Berthold et al. identified a novel pentacyclic triterpene, lupeolic acid, from frankincense gum resins which are used to inhibit cytosolic phospholipase A2 $\alpha$ responsible for inflammation [41,132]. Hoernlein et al. (1999) reported antiproliferative property of AK $\beta B A$ and noted that A keto- $\beta$-BA (KBA) 
inhibited 5-lipooxygenase. Further, they tested acetyl-11-keto-beta-BA on growth performance of leukemic cell growth; the finding obtained from this experiment suggested that apoptosis induced in human leukemia-60 and CCRF-CEM was due to inhibition of Topoisomerase I in these cells [38]. Clarisse Cuaz-Pérolin et al. (2008) studied the effect of $\mathrm{AK} \beta \mathrm{BA}$ on the growth of atherosclerotic lesions in apolipoprotein of mice. They observed that AK $\beta B A$ strongly reduced the IKK activity immunoprecipitated from LPS-stimulated mouse macrophages and mononuclear cells leading to reduced phosphorylation of I $\mathrm{KB} \alpha$ and inhibition of p65/NF- $\mathrm{B}$ activation [44]. Vanessa et al. (2004) studied the effects of connected food consumption on the bioavailability of different BAs. Data exposed comprehensive kinetics of BAs after the oral supply of extract and established a relationship between food intake and pharmacokinetic of BAs [45]. Syrovets et al. (2005b) studied the role of ABAs on activity of IKK and observed that ABAs promoted apoptosis in an androgen-independent PC-3 prostate cancer cell by inhibiting IKK in both in vitro and in vivo condition. On the basis of their findings, they concluded that AK $\beta B A$ and associated molecules acting on IKK might offer a novel method for the treatment of chemoresistant human tumors such as androgen-independent human prostate cancers [42,43]. Berthold et al. (2006) observed that extract of B. sacra inhibited the growth of prostate cancer cells of chemotherapy-resistant human PC-3 in vitro and provoked apoptosis as shown by activation of caspase 3 and the induction of DNA fragmentation $[45,132]$.

\section{Emblica officinalis}

It is an elegant decorative tree and attains a height of $18 \mathrm{~m}$ and, in rare cases, up to $30 \mathrm{~m}$. The emblic is of countless significance in Asiatic medicine not only as an antiscorbutic but also in the dealing of diverse sicknesses particularly those related with gastric organs [43]. For such use, the fruit juice is extracted in the form of a sherbet or is fermented. In its latter state, it is used for jaundice, coughs, dyspepsia, etc. The dried chips of the epithelium are mixed with honey and grape juice for treating various minor physiological disorders. Extract obtained from emblic with Terminalia chebula and Terminalia bellirica locally known as Triphala is given for prolonged dysentery, hemorrhoids, biliousness, enlarged liver, and other disorders. Dried powder fruit is an active remedy as it stimulates the respiratory glands. The liquor, that releases from persistent fruit, has operated as an eyewash for swollen eyes [46-48].

Essential oils of Emblica contain tannins, ellagitannins (corilagin, geraniin, and chebulagic acid), alkaloids, phenolic compounds, amino acids, and carbohydrates. Juice of Emblica fruits contains the highest Vitamin C content. It is found that when the fruit is mixed with other fruits increased their dietetic excellence in terms of vitamin content. Essential oil of Emblica has various components including 3,6-di-Ogalloyl-dglucose, gallic acid (Fig. 1i), chebulinic acid, 1-0-galloyl-betaD-glucose, ellagic acid, quercetin (Fig. 1j), chebulagic acid, corilagin, 1,6-di-O-galloyl beta D glucose, 3 ethylgallic acid (3 ethoxy 4,5 dihydroxy benzoic acid), and isostrictiniin [49]. Habib-ur-Rehman et al. reported that Phyllanthus emblica contains flavonoids, kaempferol-3-0alpha L-(6" methyl) rhamnopyranoside, and kaempferol-3-0-alpha-L (6" ethyl) rhamnopyranoside [48]. Another acylated apigenin glucoside (apigenin-7-0-(6" butyryl beta gluco-pyranoside) was extracted from the leaves of $P$. emblica together with the known compounds such as methyl gallate, gallic acid, 1,2,3,4,6-penta-0-galloylglucose, and luteolin-4'-oneohesperiodoside [45]. A concoction made by dehydrated fruit in water for at least $12 \mathrm{~h}$ has also worked as an eyewash. Liquor prepared from the inflamed fruits is recommended as a treatment for gastritis, anemia, jaundice, some cardiac problems, nasal congestion, and urine retention. The flowers and roots are also used in a number of ways. A gel made from the overcooked seeds and oil is used to skin infirmities. The various preparations of seed are prescribed in treating asthma, bronchitis, diabetes, and fevers. Seeds have enzymes such as lipolytic and proteolytic as well as phosphatides with a minor quantity of essential oil. Nosál'ová et al. considered the medicinal importance and observed antitussive property of E. officinalis gaertn. In conscious cats by stimulation of the tracheobronchial mucous areas of windpipe [46].
They noted that a dose at $50 \mathrm{mg} / \mathrm{kg}$ body weight. Applied orally, the cough tyrannical outcome of E. officinalis was not clear. A fundamental dose (200 mg/kg body weight) of this component applied orally was found extra effective, mainly in waning cough exertions (NE), incidence of cough $(\mathrm{NE} / \mathrm{min}[-1])$, and the number of cough rounds in inspirium (IA+) and expirium (IA-) was highly noticeable. These outcomes showed that the cough exploitive activity of E. officinalis is dose-dependent. It is well reported and easy to demonstrate that antitussive activity of $E$. officinalis is less effective in comparison to classical narcotic antitussive drug codeine, but more effective than the non-narcotic antitussive agent dropropizine [48]. It was proposed that the antitussive activity of the dehydrated extract of $E$. officinalis was due not only to antispasmolytic, antiphlogistic, and antioxidant properties but also to its effect on mucus secretion in the airways. Phytochemicals are currently believed as one of the most significant approaches in the control of cancer. Essential oil is treasured for its distinctive tannins and flavonoids which showed very influential antioxidant properties. The inhibition of tumor occurrences by fruit extract Emblica estimated on the two-stage method of skin carcinogenesis in Swiss Albino mice [51].

\section{Aloe vera}

A. vera is a herbal member of the lily family. It has a rich source of juice and can be comparable to a cactus [50]. It has fleshy, gray-green leaves in an attractive rosette display. There are over 200 species of A. vera. A. vera comprises up to 75 nutrients and 200 active compounds including vitamins, enzymes, minerals, sugar, glyconutrients, lignin, anthraquinones, saponins, salicylic acid, and amino acids [51]. The utmost advantageous variety of $A$. vera is $A$. vera barbadensis [52]. Specifically, $A$. vera, both taken orally and through relevant dressings is actual treatment in cases of frostbite, different types of sores, any kind of skin wound, as well as eruptions and scorches, epidemics, urticaria, hypersensitive reaction, scratches, herpes lacerations, pimples, insect bites, prickles, scalp irritation, psoriasis, and sunburn pain [53,54]. It eases dark facial acne and decreases the strength of coloration. It is applied as a conditioner and supportive in eliminating departed cells. It is also cooperative in permeation of vigorous substances [55-57]. $A$. vera holds two different classes of Aloins:

1. Nataloins, which produce oxalic acids and picric (Fig. $1 \mathrm{k}$ ) with nitric acid, and does not provide a red coloration with nitric acid and

2. Barbaloins, which produced chrysammic acid $\left(\mathrm{C}_{7} \mathrm{H}_{2} \mathrm{~N}_{2} \mathrm{O}_{6}\right)$, aloetic acid $\left(\mathrm{C}_{7} \mathrm{H}_{2} \mathrm{~N}_{3} \mathrm{O}_{5}\right)$, and picric and nitric acid with oxalic acids.

This second cluster may be separated into a-barbaloins, b-barbaloins obtained from Barbados aloes as well as socotrine and Zanzibar aloes. Reddening occurs by nitric acid only when tepid in the cold. Nataloin creates sunnyyellow scales. Barbaloin creates buttery prismatic crystals. The plant offers six antiseptic means, namely, salicylic acid, lupeol, nitrogen, urea, phenols cinnamonic acid, and sulfur. All materials were identified as antiseptics as they destroy or regulate fungus, microbes, mold, and germs revealing that the plant is capable of removing many inner and exterior infections of the body. Lupeol and salicylic acid are two very active painkillers. It includes three anti-inflammatory fatty acids, namely, cholesterol, campesterol, and $\beta$-sitosterol. These are used in the treatment of injuries, predicaments, scratches, allergic scuff, retort, arthritis, rheumatic fever, ulceras, and acid indigestion well as a variety of inflammatory problems of the digestive tract and internal organs such as the stomach, colon, small intestine, liver, pancreas, and kidney. $\beta$-sitosterol is another dominant anti-cholesterol which aides to lower dangerous cholesterol intensities extremely beneficial for heart patients. There are at least 23 polypeptides present in aloe juice which can aid the immune system of the body to protect it from various ailments and disarrays. The polypeptides, aloe-emodin and aloe lectins are now also applied to cure cancer. Stanle et al. examined $A$. vera gel for its microbial activity [58]. He used ethanol, methanol and an aqueous extract solvent for extraction. He reported that aqueous extract had the maximum production (19.0 g) after extraction in comparison to ethanol (18.40 g) and methanol (18.0 g). However, ethanol is still considered as the best solvent for extraction. Agar well diffusion method was used to check the vulnerability of $E$. coli, S. aureus, and C. albicans to 
the crude extracts of $A$. vera gel. They used both negative and positive controls by taking gentamycin as the positive control while dimethyl sulfoxide being the negative control [56]. The ethanol extract proved better in comparison to aqueous extract as it showed to decrease the growth of $C$. albicans, $S$. aureus, and $E$. coli with zones of inhibition of 4,5 , and $6 \mathrm{~mm}$ while the water extract had zones of inhibition of 3,4 , and $6 \mathrm{~mm}$, respectively. The lowest response registered by methanol extract as it decreased the growth of E. coli $(3 \mathrm{~mm})$ only. Another report by Ferro et al. suggested that $A$. vera leaf gel is capable to inhibit the growth of two Gram-positive bacteria Shigella flexneri and Streptococcus pyogenes [59]. Particular secondary metabolites of $A$. vera such as anthraquinones [58,59] and dihydroxyanthraquinones [60] as well as saponins [61,62] have antimicrobial activity. Further, Shamim et al. reported the highest inhibition by ethanol extracted from A. vera baradenisis against Candida species [63]. Polysaccharide component from whole plant material has antimicrobial activity as it encourage phagocytic leukocytes [64]. Bajwa and Shafique examined the antipathogenic activity of $A$. vera extract against Alternaria alternata, Alternaria citri, and Alternaria tenuissima and found that $A$. vera extract made a toxic effect on mycelial growth and proliferation of these member of alternaria [65]. Further, he noted that a dose of A. vera gel at $0.25 \%$ was more pronounced against Aspergillus flavus compare to Aspergillus niger. Another report published explained the antifungal effect of $A$. vera on various varieties of Aspergillus including A. flavus, Aspergillus glaucus, and on other fungal agents such as C. albicans, Candida tropicalis, Trichophyton mentagrophytes, and Trichophyton rubrum [66-68]. The dose of $A$. vera gel at $0.35 \%$ was active at the maximum against all tried fungi. At this dose, mycelial growth decreased at $24.29 \%$ in $A$. niger, $9.26 \%$ in $A$. flavus, and only $6.24 \%$ in Penicillium digitatum. Cock also noticed antifungal property of $A$. vera gel by testing it on A. niger [67]. In view of Arunkumar and Muthuselvam, acetone extract of $A$. vera showed the highest antifungal activity against $A$. niger and A. flavus [69]. Acemannan, from $A$. vera gel, has antiviral and antitumoral properties. Lee et al. extracted and purified acemannan from $A$. vera and observed that acemannan has positive effect phenotypic and functional maturation of immature dendritic cells [68].

\section{Cuminum cyminum}

C. cyminum, a member of family Apiaceae, has been commonly cultivated in Asia, Africa, and Europe from very early periods of civilization and considered as one of the earliest cultivated herbs. Cumin seeds are used in traditional remedies and considered eupeptic, acerbic, antispasmodic, and carminative and have been applied to cure mild digestive ailments, diarrhea, indigestion, gassiness, morning sickness, bellyache, dyspeptic headache, and inflating and are said to encourage the assimilation of other herbs and to improve liver function. It is used to treat bronchopulmonary disorder as well as a painkiller. Seeds of cuminum are used to treat lambago and rheumatism. Essential oil of C. cyminum $\mathrm{L}$ is an antibacterial, anti-inflammatory, a palliative hemolytic, or antienzymatic action [68]. Seeds of $C$. cyminum are carminative, sweet-smelling, stomachic, intoxicating, caustic, and freshening in effect [69]. Cumin seed oil is used as multifunctional glowing dyes or in topical coagulating ointment [70]. In the treatment of scabies, a mixture of castor oil and alcohol is generally applied, and it was noted by Joshi and his team that it significantly controlled scabies [71]. Various scientists studied the composition of cumin seeds and discovered that they possessed various classes of secondary metabolites such as hydrocarbons, monoterpene, oxygenated monoterpenes, saturated and unsaturated fatty acids, oxygenated sesquiterpenes, aldehydes, esters, and ketones [72-74]. Other reports mentioned some primary metabolites such as fatty acids, triacylglycerols, polysaccharides, and lignin in cumin seeds $[75,76]$. Yetim and co-workers studied the composition of seed and reported a nonspecific lipid transfer protein [77]. Reports of El-Sawi and Mohamed, Al-Bataina et al., Maiga et al., and Milan et al. mentioned that cumin seeds have nutrients such as amino acids, vitamins, protein, minerals, carbohydrates (sugars, starch), tannins, dietary fiber components, and phytic acid [78-83]. Oils and extract of cumin seeds have antimicrobial activity against useful and pathogenic Gram-positive and Gram-negative bacterial strains [73,82-85]. Dorman and Deans studied the antimicrobial activity of oil and extract of cumin seeds and found that both oil and extract of cumin seeds inhibited the growth of Klebsiella pneumonia [86]. They suggested that limonene, eugenol, pinene, and some other minor constituents contribute to the antimicrobial activity of cumin oil. Further, Burt observed that carvacrol chemically known as 5-isopropyl-2-methylphenol devises antimicrobial activity against both Gram-positive and negative bacteria [87]. Various reports clearly indicate that cumin oil has antifungal property against food, soil, human, and animal pathogens such as dermatophytes Vibrio spp., aflatoxins, yeasts, and mycotoxin producers $[73,83,86,87]$. It is also observed that sufficient supplementation of cumin in diet decreases the chances of colon cancer in rats induced by colon-specific carcinogen. In those animals that received a sufficient quantity of cumin in their food were found healthy and showed no sign of colon tumors [88,89]. Cumin supplementation in diet can decrease the chances of benzopyreneinduced forestomach tumorigenesis, 3-methylcholanthrene induced uterine cervix tumorigenesis and 3-methyl-4-dimethyaminoazobenzene induced hepatomas in mice. The capacity of cumin to inhibit various cancer cells is due to its ability to modulate carcinogen metabolism through carcinogen/xenobiotic metabolizing Phase I and Phase II enzymes $[90,91]$.

Cumin oil has influences on compound-metabolizing enzymes and acid-sol compound in plant seeds and regulate the sulfhydryls in liver [68]. Hussain et al. stated the key constituents are cuminal and safranal $32.26 \%$ and $24.46 \%$, respectively [72]. Soniya et al. studied the antibacterial property of cuminum extract against $E$. coli and found that it could control the infection cause by E. coli [92]. Another study indicated that essential oil of C. cyminum is useful to inhibit the infection caused by E. coli P. aeruginosa and Salmonella sp. Experiment conducted by Keskin and Toroglu was sufficient to show that methanol extracts of cuminum have no inhibitory effect against pathogen like Rosenbergia rubra [91]. Ouattara et al. suggested that antibacterial activity of cuminum due to carvone and carvacrol was found in its volatile oil [94]. Shetty et al. studied the effect of essential oil of cumin on ungi, yeast, and bacteria [95]. According to their findings cumin, essential oil had high effects on fungi and yeast than that of bacteria.

\section{Rhazya stricta}

R. stricta decne (R. stricta) is the member of family Apocynaceae, locally known as harmal, which is commonly found in Asia. It was the main source of raw material used to treat several types of physiological disorder including sore throat, rheumatic pain, syphilis, helminthiasis, diabetes, fever, inflammatory conditions, and other diseases. R. stricta has more than 100 indole alkaloids including akuammidine, rhazinilam, and tetrahydrosecamine $[95,96]$. Baeshen et al. studied the chemical composition of leaves of $R$. stricta and found that leaves have several types of primary and secondary metabolites including flavonoids, glycosides, triterpenes, tannins, volatile bases, and probably other substances [97]. Due to its medicinal properties, scientists explored it in all aspects of studies including phytochemistry, antimicrobial activity, central nervous system (CNS) depression and also in general pharmacology as well as the toxicity of the plant [98-104]. There are several reports which explained the biological and physiological effect of the extract obtained from leaves of $R$. stricta. Extract obtained from leaves of $R$. stricta caused drowsiness, insensibility, reduced motor movement and various other effects on brain activity. Ahmad et al. studied the effect of leaves, flower and fruit on joint infection and cancer, and found some positive response [99]. Baeshin et al. claimed to study the first time genotoxic effect of the R. stricta leaf aqueous extract as an antifungal agent against Saccharomyces cerevicae auxotrophic mutant [105]. Furthermore, in another study, Baeshin et al. reported the biochemical and molecular evaluation of genetic effects of $R$. stricta (decne) leaves extract on Aspergillus terreu [106]. However, there are still very few reports that deal with the antimicrobial effects of the leaf extract of $R$. stricta. Ansah et al. and Baeshin et al. observed in their study with Cryptolepis sangvinolehta and A. terreus that leaf extracts of $R$. stricta produced free radicals which can interact with plasmid DNA to identify the deletion $[106,107]$. The ability of $R$. stricta leave extract 
to apply a stress on the bacteria was confirmed by results of sodium dodecyl sulfate-polyacrylamide gel electrophoresis protein profile, the decrease of total protein and expression of new proteins due to the treatment. Such type of stress caused the induction and expression of proteins in treated bacteria. Similar effects were observed by Baeshin et al., and Burt and Reinders in S. cerevicae and E. coli by the application of oregano and thyme essential oil, both worked as strong antimicrobial agents $[106,108,109]$. Burt explained the mode of action of secondary metabolites as mostly being obtained by essential oil against bacterial cell [89]. He suggested that the systematic damage in bacterial cell followed the following events:

1. Degradation of the cell wall damage, cytoplasmic membrane proteins, the binding of proteins;

2. Leakage of cell contents;

3. Coagulation of cytoplasm; and

4. Depletion of the proton motive force.

The leaves extract of $R$. stricta reduced the quantity of triglycerides, lowdensity lipoprotein-c, cholesterol, uric acid, and creatinin and enhanced the concentration of high-density lipoprotein-c. The leaves extract of $R$. stricta increase and decrease all the components above with any effect on the liver and kidney function. Singhal et al. used high doses of leaves extract to study the toxic effect on physiological parameters [110]. He found that supply of $0.25 \mathrm{~g} / \mathrm{kg} /$ day leaves of $R$. stricta increased the cholesterol level in sheep within 42 days. He concluded that $R$. stricta has capacity to cure hypercholesterolemia and hypertriglyceridemia. However, he suggested the need for further investigation to confirm the results obtained by him. He also suggested further study of the possible mechanism of action of leaves extract of $R$. stricta on human cardiovascular disorders. Shahat et al. (2016) investigated the antitumor activity of $R$. stricta in chemically-induced hepatocellular carcinoma (HCC) in rats. They observed that findings of experiment support antitumor efficacy of $R$. stricta against HCC and work as hepatoprotective properties, antiproliferative activity, and antiangiogenic potential [100]. El-Awady et al. (2015) investigated the anticancer potentiality of $R$. stricta grown in Saudi Arabia. Different extracts were utilized against HCC (HepGII) and colon cancer (CaCo) cell lines. Extract showed the highest cytotoxic effect among all extracts with caco cells (IC50 $25 \mu \mathrm{g}$ / $\mathrm{ml}$ and $35 \mu \mathrm{g} / \mathrm{ml}$ ) and HepG2, respectively [101].

\section{Calotropis procera}

C. procera (Ait) R.Br. (Asclepiadaceae) is a plant which is widely cultivated throughout the whole region of Asia and Africa and the Middle East. This plant is commonly acknowledged due to the richness of latex [110]. Latex is a mixture of various secondary metabolites, such as glycosides, tannins, and many proteins, among others $[112,113]$. C. procera is an important source for Ayurveda. Calotropis is represented by two species, namely, Calotropis gigantea (Linn.) R.Br. and C. procera (Ait.) R.Br [109]. It has been broadly recycled in the Sudanese, Unani, Arabic, and Indian traditional medicinal system so as to treat various diseases, namely, leprosy, ulcers, piles and diseases of the spleen, liver, and abdomen [114]. Various parts of Calotropis have several biological activities such as proteolytic, antimicrobial, larvicidal, nematocidal, anticancer, and anti-inflammatory [115]. The latex of Calotropis can be applied to heal the wound and also used as anti-diarrhea, antiinflammatory, and anti-rheumatism agent [116]. The anti-bacterial property of Calotropis latex is due to the presence of active components such as calatin, mudarin, and calotropin $[117,118]$. Shittu et al. studied the effect of latex obtained from $C$. procera on total viable count and found that the ethanolic extract of both leaf and latex reduced the growth of fungi, namely, $R$. stolonifera [119]. Almost similar findings were reported by Kareem et al. against fungal strains [120]. Freitas et al. examined the reducing power of latex extract of $C$. procera against Fusarium solani [120].

\section{Nerium oleander}

$N$. oleander is a perennial shrub that belongs to Apocynaceae (dogbane family). All sections of the plants are toxic. However, the sections such as leaves, roots, and root bark can be applied to cure different disorders. Charka, a well-known Indian Practitioner of Ayurveda, used leaves of nerium to treat skin disease including leprosy. Various reports published on nerium suggested that it can be used in various disease such as dermatitis, carbuncles, herpes, eczema, lesions, psoriasis, verrucae, asthma, scabies, slops, ringworm, dysmenorrheal, epilepsy, malaria, abortifacients, emetics, heart tonics, and tumor [121]. Khare studied the properties of $N$. oleander and observed that it can actually cause the ulcers and induce abortion [122]. Hseini et al. reported that leaves of $N$. oleander contained very high amounts of polyphenol [123]. The major secondary metabolites of $N$. oleander are cinnamic acid, an antioxidant, anti-diabetic, and hepatoprotective [124]. Rashan et al. 2011 studied anticancer activities of extracts and isolated cardenolides. They observed that results were in agreement with the ethnomedicinal use of Streptocaulon tomentosum and $N$. oleander. The highly active compounds from both species were monoglycosidic cardenolides having the $3 \beta, 14 \beta$-dihydroxy-5 $\beta$-card-20(22)-enolide structure with or without an acetoxy group at C-16. The findings showed that the cytotoxic effects are made by the inhibition of the plasma membrane-bound $\mathrm{Na}(+) / \mathrm{K}(+)$-ATPase [125]. Mohadjerani conducted an experiment to study the property of leaf extracts of nerium and found that extract with methanolic decoction and $\mathrm{N}$-butanol extract showed more activity than that of phenolic extract. On the basis of his findings, Mohadjerani explained that leaves extract of nerium in different solvents has different activity [126]. Smith et al. tested a hot aqueous extract of $N$. oleander leaves against the treatment of the tumor and observed that it can be useful to inhibit the growth of fibroblast factor-2 [127]. On the basis of results obtained from the study, it was concluded that $N$. oleander leaves have anti-tumor activity. Another team of Erdemoglu studied medicinal capacity of leaves and flower of $N$. oleander and found that both leaves and flower have antiinflammatory activity against paw edema in mice without causing any gastric damage [128]. Further, Rout et al. proved that leaf extract of $N$. oleander inhibited CNS depressant activity in tested animal models [129]. Moreover, macerated leaves of oleander have been used topically to treat baldness, dermatitis, syphilis, and cancers [130].

\section{CONCLUSION}

Medicinal plants have continued to contribute to the main sources of medications for a very long time. Numerous medicines are results either directly or indirectly from plant products. In the past decade, research in medicinal plants has been intensified due to the scientific evaluation of traditional drugs to cure various diseases. Frankincense holds the primary position among the medicinal plants of the Dhofar region in terms of exploration of its active constituents. The anti-inflammatory, anti-arthritic, antiproliferative, anti-microbial, and analgesic effect of its gum resin can reduce inflammation and pain in the body and relieve related symptoms of many diseases. Recently, scientists are focusing on anti-cancer properties of gum resin obtained from various species of frankincense and other secondary metabolites obtained from different medicinal plants. Wide-ranging studies on frankincense and other medicinal plants could be proved to be a precise method to finding possible new balancing or substitutive natural medicines to regulate, treat or avoid various diseases.

\section{AUTHOR'S CONTRIBUTION}

All authors significantly contributed in this review.

\section{CONFLICT OF INTERESTS}

Authors declare they have no conflict of interests.

\section{REFERENCES}

1. Fabricant DS, Farnsworth NR. The value of plants used in traditional medicine for drug discovery. Environ Health Perspect 2001;109:69-75.

2. Edith A, Mofolusho F, Omonike O, Larry A. In vivo antimalarial and cytotoxic properties of Annona senegalenisis extract. Agric J Tradit Complement Act Med 2005;3:138-9. 
3. Thompson RC. A Dictionary of Ancient Botany. London: ???; 1949.

4. Siddiqui MM, Afaq SH, Asif M. Chemical Standardization of 'Kundur' (Oleo-Gum-Resin of Boswellia serrate Roxb). Ancient Sci Life IV 1984;1:48-50.

5. Sultana A, Rahman KU, Padmaja AR, Rahman SU. "Boswellia serrata Roxb. A traditional herb with versatile pharmacological activity: A review. Int J Pharm Sci Res 2013;4:2107.

6. Miller A, Morris M. Plants of Dhofar: The Southern Region of Oman: Traditional, Economic, and Medicinal Uses. Oman: Office of the Advisor for Conservation of the Environment, Diwan of the Royal Court, Sultanate of Oman; 1988.

7. Afsharypuor S, Rahmany M. Essential oil constituents of two african olibanums available in Isfahan commercial market. Iran J Pharmacol Sci 2005; $1: 167-70$.

8. Michie CA, Cooper E. Frankincense and myrrh as remedies in children. J R Soc Med 1991;84:602-5.

9. Maloney GA. Gold, frankincense, and myrrh: An introduction to Eastern Christian spirituality. New York: Crossroads Pub. Co.; 1997.

10. El-Sherbini GT, El Gozamy BR, Abdel-Hady NM, Morsy TA. Efficacy of two plant extracts against Vaginal trichomoniasis. J Egypt Soc Parasitol 2009;39:47-58.

11. Van Vuuren SF, Kamatou GP, Viljoen AM. Volatile composition and antimicrobial activity of twenty commercial frankincense essential oil samples. S Afr J Bot 2010;76:686-91

12. Walsh ME, Reis D, Jones T. Integrating complementary and alternative medicine: Use of myrrh in wound management. J Vasc Nurs 2010;28:102.

13. Wanner J, Schmidt E, Bail S, Jirovetz L, Buchbauer G, Gochev V, et al. Chemical composition and antibacterial activity of selected essential oils and some of their main compounds. Nat Prod Commun 2010;5:1359-64.

14. Jarić S, Mitrovi' M, Djurdjević L, Kostić O, Gajić G, Pavlović D, et al. Phytotherapy in medieval Serbian medicine according to the pharmacological manuscripts of the chilander medical codex (15-16th centuries). J Ethnopharmacol 2011;137:601-19.

15. Yousef JM. Identifying frankincense impact by biochemical analysis and histological examination on rats. Saudi J Biol Sci 2011;18:189-94.

16. Ammon HP. Boswellic acids in chronic inflammatory diseases. Planta Med 2006;72:1100-16.

17. Al-Harrasi A, Al-Saidi S. Phytochemical analysis of the essential oil from botanically certified oleogum resin of Boswellia sacra (Omni Luban). Molecules 2008;13:2181-9.

18. Ayoola GA, Coker HA, Adesegun SA, Adepoju-Bello AA, Obaweya K, Ezennia EC, et al. Phytochemical screening and antioxidant activities of some selected medicinal plants used for malaria therapy in South Western Nigeria. Trop J Pharm Res 2008;7:1019-24.

19. Kumar A, Ilavarasn R, Jayachandran T, Decaraman M, Aravindhan P, Padmanaban N, et al. Phytochemical investigation on a tropical plant. Pak J Nutr 2009;8:83-5.

20. Marinova D, Ribarova F, Atanasoval M. Total phenolics and flavonoids in Bulgarians vegetables. J Univ Chem Technol Met 2005;40:255-9.

21. Sreevidya N, Mehrotra S. Spectrophotometric method for estimation of alkaloids precipitates with Dragendorff's reagent in plant materials. J AOAC Int 2003;86:1124-7.

22. Okwu DE, Josiah C. Evaluation of the chemical composition of two Nigerian medicinal plants. Afr J Biotech 2006;5:357-61

23. Hamidpour R, Soheila H, Mohsen H, Roxanna H. Frankincense (Boswellia species): The novel phytotherapy for drug targeting in cancer. Arch Cancer Res 2016;4:46-8.

24. Rijkers T, Ogbazghi W, Wessel M, Bongers F. The effect of tapping for frankincense on sexual reproduction in Boswellia papyrifera. J Appl Ecol 2006;43:1188-95

25. Siddiqul MZ. Boswellia serrata, a potential antiinflammatory agent: An overview. Indian J Pharm Sci 2011;73:255-61.

26. Kindeya GH. Ecology and Management of Boswellia papyrifera (Del.) Hochst. Dry Forest in Tigray, Northern Ethiopia (Ph.D. Thesis). Gottingen, Germany: Culvillier; 2003.

27. Moussaieff A, Mechoulam R. Boswellia resin: From religious ceremonies to medical uses; a review of in-vitro, in-vivo and clinical trials. J Pharm Pharmacol 2009;61:1281-93.

28. Ota M, Houghton P. Boswellic Acid with Acetylcholinesterase Inhibitory Properties from Frankincense" $53^{\text {rd }}$ Annual Congress Organized by Society of Medicinal Plants, Societa Italiana di Fitochimica Florence; 2005. p. 339

29. Notermans S, Hoogenboom-Verdegal A. Existing and emerging foodborne diseases. Int J Food Microbiol 1992;15:197-305.

30. Souza EL, Lima EO, Freire KR, Sousa CP. Inhibitory action of some essential oils and phytochemicals on the growth of moulds isolated from foods. Braz Arch Biol Technol Curitiba 2005;2:245-50.

31. Camarda LT, Vita D, Rosa P, Domenico S. Chemical composition and antimicrobial activity of some oleogum resin essential oils from Boswellia spp. (Burseraceae). Annal Chim 2007;97:837-44.

32. Ali A, Wurster M, Arnold N, Teichert A, Schmidt J. Chemical composition and biological activities of essential oils from the oleogum resins of three endemic soqotraen Boswellia species. Rec Nat Prod 2008;2:6-12

33. Khosravi S, Mahmoodian H, Moghadamnia A. The effect of Frankincense in the treatment of moderate plaque induced gingivitis: A double blinded randomized clinical trial. Daru 2011;19:288-94.

34. Kavanaugh NL, Katharina R. Selected antimicrobial essential oils eradicate Pseudomonas spp. and Staphylococcus aureus biofilms. Appl Environ Microbiol 2012;78:4057-61.

35. de Rapper S, Van Vuuren SF, Kamatou GP, Viljoen AM, Dagne E. The additive and synergistic antimicrobial effects of select frankincense and myrrh oils - a combination from the pharaonic pharmacopoeia. Lett Appl Microbiol 2012;54:352-8

36. Estrada AC, Syrovets T, Pitterle K, Lunov O, Buchele B, SchimanaPfeifer J, et al. Tirucallic acids are novel pleckstrin homology domaindependent Akt inhibitors inducing apoptosis in prostate cancer cells. Mol Pharmacol 2010;77:378-87.

37. Tatiana S, Büchele B, Gedig E, Slupsky JR, Simmet T. Acetyl-boswellic acids are novel catalytic inhibitors of human topoisomerases I and Ii . Mol Pharmacol 2000;58:71-81.

38. Hoernlein RF, Orlikowsky TH, Zehrer C, Niethammer D, Sailer ER, Simmet TH, et al. Acetyl-11-keto- $\beta$-boswellic acid induces apoptosis in HL-60 and CCRF-CEM cells and inhibits topoisomerase I. J Pharmacol Exp Ther 1999;288:613-9.

39. Tatiana S, Büchele B, Krauss C, Laumonnier Y, Simmet T. Acetylboswellic acids inhibit lipopolysaccharide-mediated TNF- $\alpha$ induction in monocytes by direct interaction with I $\mathrm{B}$ kinases. J Immunol 2005a;174:498-506.

40. Bone K. Boswellia and brain inflammation. Mediherb US e-Monitor 2011;37:1-2.

41. Zugmaier BB, Simmet T. Analysis of pentacyclic triterpenic acids from frankincense gum resins and related phytopharmaceuticals by highperformance liquid chromatography. Identification of lupeolic acid, a novel pentacyclic triterpene. J Chromatogr B 2003;791:21-30.

42. Sterk V, Büchele B, Simmet T. Effect of food intake on the bioavailability of boswellic acids from a herbal preparation in healthy volunteers. Planta Med 2004;70:1155-60.

43. Tatiana S, Gschwend JE, Büchele B, Laumonnier Y, Zugmaier W, Genze $\mathrm{F}$, et al. Inhibition of IкB kinase activity by acetyl-boswellic acids promotes apoptosis in androgen-independent PC-3 prostate cancer cells in vitro and in vivo. J Biol Chem 2005b;280:6170-80.

44. Büchele B, Zugmaier W, Estrada A, Genze F, Syrovets T, Paetz C, et al. Characterization of $3 \alpha$-acetyl-11-keto- $\alpha$-boswellic acid, a pentacyclic triterpenoid inducing apoptosis in vitro and in vivo. Planta Med 2006;72:1285-9.

45. Veena K, Shanthi P, Sachdanandam P. The biochemical alterations following administration of kalpaamruthaa and Semecarpus anacardium in mammary carcinoma. Chem Biol Interact 2006;161:69-78.

46. Khan KH, Roles of Emblica officinalis in medicine-a review. Bot Res Int 2009;2:218-28.

47. Zhang LZ, Zhao WH, Guo YJ, Tu GZ, Lin S, Xin LG. Studies on chemical constituents in fruits of Tibetan medicine Phyllanthus emblica. Zhongguo Zhong Yao Za Zhi 2003;28:940-3.

48. Habib-ur-Rehman, Yasin KA, Choudhary MA, Haque R, Bin-Hafeez B, Ahmad I, et al. Studies on the chemical constituents of Phyllanthus emblica. Nat Prod Res 2007;21:775-81.

49. El-Desouky SK, Ryu SY, Kim YK. A new cytotoxic acylated apigenin glucoside from Phyllanthus emblica L. Nat Prod Res 2008;22:91-5.

50. Nosál'ová G, Mokrý J, Hassan KM. Antitussive activity of the fruit extract of Emblica officinalis Gaertn (Euphorbiaceae). Phytomedicine 2003;10:583-9.

51. Sancheti G, Jindal A, Kumari R, Goyal PK. Chemopreventive action of Emblica officinalis on skin carcinogenesis in mice. Asian Pac J Cancer Prev 2005;6:197-201.

52. Akinyele BO, Odiyi AC. Comparative study of the vegetative morphology of the existing taxonomic status of Aloe vera. J Plant Sci 2007;2:558-63.

53. Park YI, Jo TH. Perspective of industrial application of Aloe vera. In: Park YI, Lee SK, editos. New Perspective on Aloe. New York, USA: Springer Verlag; 2006. p. 191-200.

54. Dennis P, Zhu YF. Evaluation of Aloe vera gel gloves in dry 
skin associated with occupational exposure. Am J Infect Control 2003;31:40- 2

55. Suleyman A, Sema A. Investigation of in vitro antimicrobial activity of Aloe vera juice. J Anim Vet Adv 2009;8:99-102.

56. Tan BK, Vanitha J. Immunomodulatory and antimicrobial effects of some traditional Chinese medicinal herbs. Curr Med Chem 2004; $11: 1423-30$

57. Johnson M, Renisheya JM, Nancy BS, Laju RS, Aruriya G, Renola JT. Antimicrobial and antifungal activity of Aloe vera Gel extract. J Int Biomed Res 2012;3:184-7.

58. Stanle MC, Obeagu EI, Okwandu GE. Antimicrobial effects of Aloe vera on some human pathogens. Int J Curr Microbiol Appl Sci 2014;3:1022-8.

59. Ferro VA, Bradlbury F, Cameron P, Shakir E, Rahman SR, Stimson WH. In vitro suscepitibilities of Shigella flexneri and Streptococcus pyogenes to inner gel of Aloe barbadensis Miller. Antimicrob Chem Mar 2003;47:1137-9.

60. Gracia-Sosa K, Villarreal-Alvarez N, Lubben P, Pena-Rodriguez LM. Chrysophanol, an antimicrobial anthraquinone from the root extract of Colubrina gregii. J Mex Chem Soc 2006;50:76-8

61. Dabai YU, Muhammad S, Aliya BS. Antibacterial activity of anthraquinone fraction of Vilten doniana. Pak J Biol Sci 2007;14:1-3.

62. Wu YW, Ouyang J, Xiao XH, Gao YW, Liu Y. Antimicrobial properties and toxicity of anthraquinones by microcalorimetric bioassay. Chinese J Chem 2006;24:45-50.

63. Shamim S, Ahmed SW, Azhar I. Antifungal activity of Allium, Aloe and Solanum species. Pharm Biol 2004;42:491-8.

64. Pugh N, Ross SA, Elsohly MA, Pasco DS. Characterisation of aloeride, a new high molecular weight polysaccharide from Aloe vera with potent immunostimulatory activity. J Agric Food Chem 2001;49:1030-4.

65. Bajwa R, Shafique S. Apprasial of antifungal activity of Aloe vera. Mycopath 2007;5:5-9.

66. Coopoosamy RM, Magwa ML. Traditional use, antibacterial activity and antifungal activity of crude extract of Aloe excelsa. Afr J Biotech 2007;6:2406-10

67. Cock IE. Antimicrobial activity of Aloe barbadensis Miller leaf gel components. Int J Microbiol 2008;4:1937-49.

68. Lee JK, Lee MK, Yun YP, Kim Y, Kim JK, Kim YS, et al. Acemannan purified from Aloe vera induces phenotypic and functional maturation of immature dendritic cells. Int Immunopharmacology 2001;1:1275-84.

69. Arunkumar S, Muthuselvam M. Analysis of phytochemical constituents and antimicrobial activities of Aloe vera $\mathrm{L}$. against clinical pathgens. World J Agric Sci 2009;5:572-6.

70. Zaveri M, Khandhar A, Patel S, Patel A. Chemistry and pharmacology of Piper longum L. Int J Pharm Sci Rev Res 2010;5:67-76.

71. Dodson CD, Dyer LA, Searcy J, Wright Z, Letourneau DK. Cenocladamide, a diydropyridone alkaloid from Piper cenocladum. Phytochemistry 2000;53:51-4

72. Hussain A, Naz S, Nazir H, Shinwari ZK. Tissue culture of Black pepper (Piper nigrum L) in Pakistan. Pak J Bot 2011;43:1069-78.

73. Joshi SG. Medicinal Plants: Family Apiaceae. $1^{\text {st }}$ ed. Delhi: Oxford and IBH Publishing Co. Pvt. Ltd.; 2000.

74. Bettaieb I, Bourgou S, Wannes WA, Hamrouni I, Limam F, Marzouk B. Essential oils, phenolics and antioxidant activities of different parts of cumin (Cuminum cyminum L.). J Agric Food Chem 2010;58:10410-8.

75. De Martino L, De Feo V, Fratianni F, Nazzaro F. Chemistry, antioxidant, antibacterial and antifungal activities of volatile oils and their components. Nat Prod Comm 2009;4:1741-50.

76. El-Ghorab AH, Nauman M, Anjum FM, Hussain S, Nadeem M. A comparative study on chemical composition and antioxidant activity of ginger (Zingiber officinale) and cumin (Cuminum cyminum). J Agric Food Chem 2010;58:8231-3.

77. Yetim H, Sagdic O, Ozturk I. Fatty acid composition of cold press oils of seven edible plant seeds grown in Turkey. Chem Nat Compd 2008;44:634-6.

78. Ngo-Duy C, Destaillats F, Keskitalo M, Arul J, Angers P. Triacylglerols of Apiaceaae seed oils: Composition and regiodistribution of fatty acids. Eur J Lipid Sci Technol 2009;111:164-9.

79. Zaman U, Abbasi A. Isolation, purification and characterization of a nonspecific lipid transfer protein from Cuminum cyminum. Phytochemistry 2009;70:979-87.

80. El-Sawi SA, Mohamed MA. Cumin herb as a new source of essential oils and its response to foliar spray with some micro-nutrients. Food Chem 2002;77:75-80.

81. Al-Bataina BA, Maslat AO, Al-Kofahil MM. Element analysis and biological studies on ten oriental spices using XRF and Ames test. J Trace Elem Med Biol 2003;17:85-90.
82. Maiga A, Diallo D, Bye R, Paulsen BS. Determination of some toxic and essential metal ions in medicinal and edible plants from Mali. J Agric Food Chem 2005;53:2316-21.

83. Milan KS, Dholakia H, Tiku PK, Vishveshwaraiah P. Enhancement of digestive enzymatic activity by cumin (Cuminum cymonum L.) and role of spent cumin as a bionutrient. Food Chem 2008;110:678-83.

84. Gachkar L, Yadegari D, Rezaei MB, Taghizadeh M, Astaneh SA, Rasooli I. Chemical and biological characteristics of Cuminum cyminum and Rosemarinus officinalis essential oils. Food Chem 2007; 102:898-904.

85. Hajlaoui H, Mighri H, Noumi E, Snoussi M, Trabelsi N, Ksouri R, et al. Chemical composition and biological activities of Tunisian Cuminum cyminum L. essential oil: A high effectiveness against Vibrio spp. strains. Food Chem Toxicol 2010;48:2186-92.

86. Dorman HJ, Deans SG. Antimicrobial agents from plants: Antibacterial activity of plant volatile oils. J Appl Microbiol 2000;88:308-16.

87. Burt S. Essential oils: Their antibacterial properties and potential applications in foods: A review. Int J Food Microbiol 2004;94:223-53.

88. Mehdi RA, Masoomch SG, Mohammad BR, Kamkar J, Soheil A, Reza S, et al. Chemical composition and antiaflatoxicogenic activity of Carum carvi L., Thymus vulgaris and Citrus aurantifolia essential oils. Food Contr 2009;20:1018-24.

89. Boyraz N, Ozcan M. Antifungal effect of some spice hydrosols. Fitoterapia 2005;76:661-5.

90. Nalini N, Sabitha K, Vishwanathan P, Menon VP. Influence of spices on the bacterial (enzyme) activity in experimental colon cancer. $\mathrm{J}$ Ethnopharmacol 1998;62:15-24.

91. Nalini N, Manju V, Menon VP. Effect of spices on lipid metabolism in 1,2-dimethylhydrazine-induced rat colon carcinogenesis. J Med Food 2006;9:237-45.

92. Soniya M, Kuberan T, Anitha S, Sankareswari P. In vitro antibacterial activity of plant extracts against Gram positive and Gram negative pathogenic bacteria. Int J Microbiol Immunol Res 2013;2:1-5.

93. Keskin D, Toroglu S. Studies on antimicrobial activities of solvent extracts of different spices. J Environ Biol 2011;32:251-6.

94. Ouattara B, Simard RE, Holley RA, Piette GJ, Begin A. Antibacterial activity of selected fatty acids and essential oils against six meat spoilage organisms. Int J Food Microbiol 1997;37:155-62.

95. Shetty RS, Singhal RS, Kulkarni PR. Antimicrobial properties of cumin. World J Poult Biotechnol 1994;10:232-3.

96. Tanira MO, Ali BH, Bashir AK, Dhanasekaran S, Tibirica E, Alves L. Mechanism of the hypotensive action of Rhazya stricta in rats. Pharmacol Res 2000;41:369-87

97. Baeshen NA, Sahira AL, Huda AA, Ayman IE. Biochemical evaluation of the effect of Rhazya stricta aqueous leaves extract in liver and kidney functions in Rats. Nat Sci 2010;8:136-42.

98. Ali BH, Al-Qarawi H, Mousa HM, Bashir AK. Concentration of amino acids in brains of mice treated with the traditional medicinal plant Rhazya stricta. Dence. Indian J Pharmacol 2000;32:253-4.

99. Ahmad H, Ghulam RB, Latif A. Medicinal flora of the thar desertan overview of problems and their feasible solutions. Zonas Áridas 2004;8:1-11.

100. Shahat AA, Alsaid MS, Kotob SE, Husseiny HA, Al-Ghamdi AA, Ahmed HH. Biochemical and histological evidences for the antitumor potential of Teucrium oliverianum and Rhazya stricta check for this species in other resources in chemically-induced hepatocellular carcinoma. Afr J Tradit Complement Altern Med 2016;13:62-70.

101. El-Awady MA, Awad NS, El-Tarras AE. Evaluation of the anticancer activities of pomegranate (Punica granatum) and harmal (Rhazya stricta) plants grown in Saudi arabia. Int J Curr Microbiol Appl Sci 2015;4:1158-67.

102. Badreldin H, Ali A, Al-Qarawi K, Ahmed O, Bashir MT. Photochemistry, pharmacology and toxicity of Rhazya stricta Decne: A review. Photother Res 2000;14:229-34.

103. Szabó FL. Rigorous biogenetic network for a group of indole alkaloids derived from strictosidine. Molecules 2008;13:1875-96.

104. Khan S, Khan GM. In vitro antifngal activity of Rhazya stricta. Pak J Pharm Sci 2007;20:279-84.

105. Baeshin NA, Twaty N, Al-Hebshi A. Evaluation the genotoxicity of Rhazya stricta leves extract by the Saccharomyces cerevisiae auxotrophic mutats test. Egypt J Nat Toxicol 2005;2:87-100.

106. Baeshin NA, Qari SH, Sabir JS, ALhejin AM. Biochemical and molecular evaluation of genetic effects of Rhazya stricta (Decne) leafs extract on Aspergillus terreus. Saudi J Biol Sci 2008;15:25-33.

107. Ansah C, Khan A, Gooderham NJ. In vitro genotoxicity of the West African anti-malarial herbal Cryptolepis sanguinolenta and its major alkaloid cryptolepine. Toxicology 2005;208:141-7. 
108. Burt SA, Reinders RD. Antimicrobial activity of selected plant essential oils against Escherichia coli O157:H7. Lett Appl Microbiol 2003;36:162-7.

109. Adam SE, Al-Yahya MA, Al-Farhan AH. Toxicity of Nerium oleander and Rhazya stricta in Najdi sheep: Hematologic and clinicopathologic alterations. Am J Chin Med 2002;30:255-62.

110. Singhal A, Kumar VL. Effect of aqueous suspension of dried latex of Calotropis procera on hepatorenal function in rat. J Ethnopharmacol 2009; $122: 172-4$

111. WititsuwannakulD, Chareonthiphakorn N, PaceM, WititsuwannakulR. Polyphenol oxidases from latex of Hevea brasiliensis: Purification and characterization. Phytochemistry 2002;61:115-21.

112. Dubey VK, Jagannadham MV. Procerain a stable cysteine protease from the latex of Calotropis procera. Phytochemistry 2003;62:1057- 71.

113. Yelne MB, Sharma PC, Dennis TJ. Database on Medicinal Plants Used in Ayurveda. New Delhi: Central Council for Research in Ayurveda and Siddha; 2000. p. 69-73.

114. Kumar VL, Arya S. Medicinal uses and pharmacological properties of Calotropis procera. Recent Prog Med Plants 2006;11:373-88.

115. Rashan LJ, Katrin F, Myint MK, Gerhard K, Heinz HF, Joachim N, et al. Characterization of the anticancer properties of monoglycosidic cardenolides isolated from Nerium oleander and Streptocaulon tomentosum. J Ethnopharmacol 2011;134:781-8.

116. Samvatsar S, Diwanji VB. Plant sources for the treatment of jaundice in the tribals of Western Madhya Pradesh of India. J Ethnopharmacol 2000;73:313-6.

117. Hasan MQ. DNA-RAPD Fingerprinting and cytogenetic screening of genotoxic and antigenotoxic effects of aqueous extracts of Costus speciosus (Koen.) JKAU Sci 2010;22:133-52.

118. Parrotta JA. Healing Plants of Peninsular India. UK: AB International Wallingford; 2001. p. 944.

119. Shittu BO, Popoola TO, Taiwo O. Potentials of Calotropis procera leaves for Wastewater treatment. In: Proceedings of the International Conference on Science and National Development held at University of Agriculture, Abeokuta; 2004. p. 97-101.
120. Kareem SO, Akpan I, Ojo OP. Antimicrobial activities of Calotropis procera on selected pathogenic microorganisms. Afr J Biomed Res 2008;11:105-10.

121. De Freitas CD, Fábio CS, Ilka MV, Tadeu AO, Gilberto BD, Márcio VR. Osmotin purified from the latex of Calotropis procera: Biochemical characterization, biological activity and role in plant defense. Plant Physiol Biochem 2011;49:738-43

122. Khare CP. Encyclopedia of Indian Medicinal Plants. Heidelberg: Springer-Verlag; 2004. p. 328-30.

123. Hseini S, Kahouadji A. Étude ethnobotanique de la flore médicinale dans la région de Rabat (Maroc occidental). Lazaroa 2007;28:79-93.

124. Siham L, Saida O, Moha T, Nadia S, Amraoui H. Chemical analysis and antioxidant activity of "Nerium oleander" leaves. Online J Biol Sci 2014;14:1-7.

125. Adisakwattana S, Sompong W, Meeprom A, Ngamukote S, YibchokAnun S. Cinnamic acid and its derivatives inhibit fructose-mediated protein glycation. Int J Mol Sci 2012;13:1778-89.

126. Mohadjerani M. Antioxidant activity and total phenolic content of Nerium oleander L. Grown in North of Iran. Iran J Pharm Res 2012;11:1121-6.

127. Smith JA, Madden T, Vijjeswarapu M, Newman RA. Inhibition of export of fibroblast growth factor-2 (FGF-2) from the prostate cancer cell lines PC3 and DU145 by Anvirzel and its cardiac glycoside component, oleandrin. Biochem Pharmacol 2001;62:469-72.

128. Erdemoglu N, Kupeli E, Yeşilada E. Antiinflammatory and antinociceptive activity assessment of plants used as remedy in Turkish folk medicine. J Ethnopharmacol 2003;89:123-29.

129. Rout SK, Kar DM, Rout B. Study of cns activity of leaf extracts of Nerium oleander in experimental animal models. Int J Pharm Pharm Sci 2012;4:378-82.

130. Kotian SR, Pai KS, Nayak JK, Bangera H, Prasad K, Bhat KM. Biomechanical, biochemical and histological evidences for wound healing properties of indian traditional medicines. Int J Pharm Pharm Sci 2015;7:163-71. 